\title{
The Norm of Integrity in Corporate Governance Codes: Could It Be Made Enforceable?
}

\author{
B.T.M. Steins Bisschop*
}

\section{Introduction}

'Lehman' caused or marked the beginning of the present global financial and economic crisis. A common reflex reaction is to resort to more regulation to resolve the problem and avoid repetition. This article tests the results of this legal 'reflex' reaction against the backdrop of events occurring in Goldman Sachs in the year 2008.

The Great Depression will be discussed, how Lehman and Goldman Sachs fared will be compared, how narrowly the world escaped a disaster in 2008 will be explained and the limits of the classical legal response will be discussed, in particular in respect of corporate governance codes where good governance is described with the term 'integrity'. To overcome these limits, an alternative or amended legal strategy is introduced to further good governance by exploring the legal relevance of the term 'integrity' and by re-defining this general principle into a more operational term.

In this article, the faring of Goldman Sachs during the financial crisis of 2008 will be discussed, and in particular, the remarkable position of one of its board members when the circumstances that had caused the bankruptcy of Lehman also threatened Goldman Sachs. This case is considered against the background of the legal instruments that were employed to avoid the failure of Goldman Sachs, and the conclusion is that Goldman Sachs narrowly escaped the fate of Lehman. Further, an analysis is made of the legal instruments available to advance good corporate governance. From an analysis of a relevant selection of national corporate governance codes, it appears that the term integrity plays a pivotal role in these codes but cannot be considered a term which is

Prof. Dr. Bas T.M. Steins Bisschop holds a chair Corporate Law and Governance at the Faculty of Law of Maastricht University and a chair Corporate Law at Nyenrode Business University. He is partner of a boutique law firm in The Hague, The Netherlands. The author is grateful to Mandy Römkens LLM who was actively involved from the beginning of this project. She conducted in-depth research and provided important drafting suggestions. At a later stage in the project Tycho van der Meer, master student in law, economy and philosophy, provided valuable assistance, not only logistically but also by critically reviewing the text and commenting especially on the paragraphs containing observations regarding legal theory and philosophy. easily enforceable. It is a normative container concept. In modern legal theories, there is a discussion about the meaning and value of normative notions employed in a regulatory environment. Some of these theories are discussed in order to understand the norm of integrity in the corporate context. After offering deeper understanding of the normative concept of integrity in its corporate context, an effort is made to translate the norm of integrity into a legal instrument that is capable of being enforced. The amended legal strategy so found is then tested against the case of Goldman Sachs. Finally, a suggestion is made to conduct further academic research in order to employ (the example of) the redefined norm of integrity as guidance to advance good corporate governance when using normative concepts.

\section{The Great Depression: Does History Repeat Itself?}

The crash of the stock market on 24th October 1929 caused the Great Depression, a global financial and economic crisis similar to the current global crisis, but which is considered to have had a greater impact.

A failing banking system was seen as one of the major causes of the crash and the resulting crisis. The GlassSteagall Act, introduced in 1933, sought to mitigate the inherent risks related to the banking and regulatory practice at the time of allowing banks to engage both in traditional commercial banking and in investment banking activities. That Act sought to separate these activities through tighter regulation of the US banking industry. Traditional commercial banks were prohibited from engaging in investment activities such as the sale of securities. Banks engaging in investment activities, conversely, were prohibited to engage in the business of receiving deposits. The separation of retail and investment banking reduced the risk of these types of activities and was aimed at preventing that people's savings deposits would be lost as a result of speculative investment activities.

From the 1970s onwards, the Act started to erode as commercial banks started offering certain securities services. The laissez-faire, deregulatory climate of the final decades of the 20th century resulted in the Gramm-Leach-Bliley Act of November 1999, repealing 
the Glass-Steagall Act's restrictions on affiliations between banks and securities firms. As a result, commercial banks could once again be affiliated with investment banks.

As before, the expansion of the activities of the investment and commercial banks is seen as a major cause of the present financial and economic crisis. ${ }^{1}$

The 'Big-5' investment banks, Goldman Sachs, Morgan Stanley, Bear Stearns, Lehman and Merrill Lynch, were all active players in the field. Bear Stearns and Merrill Lynch encountered serious difficulties when in 2008 the market seemed to recognize that the fundamental assumptions underlying the trade in derivatives were weak and that the ratings given to these 'financial products' were wrong. The continued independent existence of these firms was in jeopardy. The government had to step in by facilitating the acquisition of Bear Stearns by JP Morgan Chase and the acquisition of Merrill Lynch by Bank of America.

In the course of 2008, Lehman was exposed to similar threats. Lehman's problems were exacerbated by the fact that the notion of moral hazard in fact impeded government from engaging in yet another operation to save a bank at the taxpayer's expense.

The failure of Lehman must be seen against this background. ${ }^{2}$ What followed was a collapse of the financial markets, including the interbank market. The trust required to maintain the market had vanished.

Finally, these aspects threatened even the most prominent of the investment banks, Goldman Sachs.

\section{Of the Giants: First Lehman, Goldman Sachs Next in Line?}

There were moral hazard considerations preventing the government from using taxpayer money to bail out those banks and bankers who were found to have managed their affairs irresponsibly and to have been paid excessively. This was also true of Goldman Sachs. ${ }^{3}$ Additionally, there were circumstances that necessitated a federal stand-off, including the multiple closely entwined connections between Goldman Sachs and the Government. $^{4}$

These facts and circumstances rendered it impossible for the US government to assist Goldman Sachs when the market pressure on Goldman Sachs became such

1. Clarke 2011, p. 28.

2. For details of the case, see Sorkin 2009 and McDonald \& Robinson 2009.

3. Sorkin 2009, p. 4.

4. As an example, the Secretary of Treasury during the financial crisis in 2007 and 2008, Henri M. Paulson Jr., was the former CEO of Goldman Sachs; the Chairman of the New York Federal Reserve Board during 2007 and 2008 was also serving as a Board director at Goldman Sachs. The Treasury Secretary, Timothy Geithner, also had had a career at Goldman Sachs; many other former GS employees were working in government positions. that its existence was at risk. Because of the widespread panic about the instability of the failing banks, public and private investors, including hedge funds and other major investors, began to withdraw their money from Goldman Sachs. The company's stock price continued to fall sharply. On Sunday 21 September 2008, both Goldman Sachs and Morgan Stanley decided to become bank holding companies in order to gain access to liquidity from the Federal Reserve. Notwithstanding these and other efforts, the stock of Goldman Sachs continued to drop. The decision to become a bank holding company seemed to have resolved the liquidity problem but not the solvability problem caused by the drop in the stock price. The bank was desperately in need of additional equity, which would not only restore public confidence but also provide leverage for further funding. ${ }^{5}$

The company's board of directors, under high pressure, undertook numerous efforts to find investors in the US, China, Japan and the Gulf States, yet without success. Ultimately, there was (renewed) contact with Berkshire Hathaway, the investment company of finance oracle Warren E. Buffet. Where contacts with the other prospective investors had been aimed at syndicating the equity contributions, it appeared that Buffet was amenable to considering financing the entire amount of $\$ 5$ billion. Ultimately, the parties agreed on a transaction involving an equity contribution of $\$ 5$ billion from Berkshire Hathaway to Goldman Sachs against stock in the form of convertible preferred shares that paid a 10 percent dividend.

The transaction provided the additional equity needed and at the same time sent a signal to the market that the company was financially stable once more. The commercially extremely attractive conditions in favour of Berkshire Hathaway had to be weighed against the effect of the transaction, which can be summarized as saving the bank from the bankruptcy that most likely would otherwise have followed.

Warren Buffet also required another promise, which he formulated in the typical Buffet style: "If I'm buying the horse, I'm buying the jockey, too". He wished to prevent an exit or partial sale of equity by board members, which might be interpreted as a vote of non-confidence resulting in a substantial dilution of Buffet's investment. The condition was imposed on the four top board members of Goldman Sachs, who were required to accept a ban on sales of their own stock in Goldman Sachs until 2011, except for a maximum of 10 percent. This lock-up condition also applied in case of board membership termination. ${ }^{6}$ Three of the four members accepted the condition but the fourth, Jon Winkelried, hesitated and announced that he was unable to comply.

He explained that he had a 'liquidity problem'. This explanation, coming from a person who had earned $\$ 51.1$ million in 2006 and $\$ 71.5$ million in 2007 , is not immediately or easily understandable. He justified his

5. Sorkin 2009, p. 484

6. Such 'lock-up' or 'stand-still' conditions are generally considered to be reasonable and proportionate in these types of transactions. 
initial refusal by pointing at the millions of costs for the maintenance of his prize-winning horse ranch which could not be covered by the sale of his Nantucket estate for $\$ 55$ million. $^{7}$

Ultimately, the other board members were able to have Jon Winkelried agree to the lock-up condition imposed by Berkshire by offering the bank's assistance in resolving these liquidity problems. The consequences of Winkelried's refusal and the subsequent frustration of the last-gasp rescue by Berkshire Hathaway would have been unacceptable.

\section{Armageddon Avoided, but Narrowly and at the Cost of Compromise}

If the $\$ 5$ billion investment had not taken place, it is fair to assume that no alternative would have been available. Goldman Sachs would have failed, exacerbating the financial crisis to such an extent that the entire banking industry in the US would have been in jeopardy. Any faltering of the financial system in the US of necessity poses a threat to the global financial system. It is no exaggeration to maintain that the fall of Goldman Sachs would pose a serious, if not actual, threat to the entire global modern financial and economic system. The consequences would be catastrophic.

The means to avoid Armageddon were in the hands of one individual, Jon Winkelried, who explained his motive to initially refuse to sign the lock-up agreement by pointing to his personal and very exceptional financial situation. Notwithstanding his extraordinary income in previous years, he had reached a situation in which 'liquidity problems' could arise. Such an explanation, coming from a person in such a position and with so much wealth, is difficult to understand and to accept. An executive board member of a major financial institution carries heavy responsibilities which render it difficult for him to devote much time to his private affairs. It is hard to conceive that a single individual 'earns' hundreds of millions of dollars, is capable of investing such a private capital responsibly and at the same time is capable of discharging his fiduciary duties towards the company. A cynical detail is that it was Jon Winkelried who in September 2008 was charged with the responsibility of urgently finding national and international investors to provide the equity investments that Goldman Sachs so desperately needed. Winkelried's efforts remained without success, and his colleague, Byron Trott, was the person who initiated the contact with Warren Buffet that ultimately proved successful. Just when the bank was really counting on him, Jon Winkelried was unable to deliver as expected. His extraordinarily high income cannot be deemed justified ex post.
In more general terms, a paradoxical situation can be noted. If a board member receives a remuneration of hundreds of millions, the implied assumption is that he is worth it. In terms of power, Winkelried had a decisive vote in the decision-making process to save Goldman Sachs. When he was asked to accept Buffet's terms, Winkelried initially refused. Such a refusal is tantamount to the use of positional power (to have a decisive vote on the deal proposed by Buffet) to serve a private interest first rather than giving priority to the interest of the company. This is exactly the opposite result of what the system of incentive through high levels of remuneration seeks to achieve; there was no alignment of interests, but rather a conflict of interests.

The justification for incentive remunerations granting extraordinarily high incomes to board members of public institutions can only be found in equally extraordinary performance. The remuneration that Winkelried was awarded was counterproductive and to some extent corrupting, as Goldman Sachs was forced to provide liquidity to a board member in order to cover that board member's private debts after the remuneration had already been paid.

\section{Lessons Learned but No Assurance}

Good corporate governance cannot exist without proper and effective remuneration strategies. The failure of the remuneration system for bankers is now on the political and legislative agenda. The necessity to come to an improved system is underlined by the particular case of Jon Winkelried.

However, other lessons can also be learned from this case. Winkelried's initial refusal could have resulted in a catastrophic situation, not only for Goldman Sachs and the US financial system, but most likely on a global scale too. In governance terms, it is impossible to justify that one person is charged with the power to allow a catastrophe to happen unless a solution to his private needs is offered. The governance question is therefore whether or not the present legal system provides us with the means to prevent such a catastrophe from occurring in comparable future situations.

\section{Resort to 'Classic' Legal Strategies}

The agency relationship between board and shareholders allowed for various legal strategies to be explored by the shareholders or board to convince and ultimately force Winkelried to sign the lock-up agreement. They could go to court, fire Winkelried, incentivize him or 
take other ex ante or ex post measures. ${ }^{8}$ It was unlikely, however, that any of these strategies would effectively make an unwilling Winkelried sign the lock-up agreement. The only solution in the given situation appeared to be that Goldman Sachs itself intervened by providing Winkelried with financial assistance to overcome his liquidity problems. The bank used its own means to assist Buffet in the provision of risk capital. In other words, Goldman Sachs itself assumed certain risks when attracting equity, whereas equity is supposed to be supplied entirely and exclusively for the risk of the capital provider.

\section{A Dilemma around the Term 'Integrity'}

The description of Winkelried's behaviour invites an ethical discussion about the morality binding bankers and the extent to which bankers may or may not serve their own interests and place those interests above the interests of the company they are serving. It is easy to claim that an executive with integrity would have to take into account the overwhelming financial, economic and societal interests attached to Goldman Sachs's survival when deciding whether or not to agree to a reasonable proposal such as the lock-up condition. In this line of reasoning, Winkelried would have to give up his resistance, sign the required agreement and even ultimately accept a possible personal bankruptcy if Goldman Sachs was unable or unwilling to provide the financial assistance that was ultimately provided.

The problem here is twofold. Firstly, imposing a duty of integrity seems to be futile when legal means to enforce the duty are absent. Secondly, an ethical dimension comes into play as it would be presumptuous to make a negative moral judgement about behaviour if that judgement cannot be sanctioned by law.

If we agree that a person of integrity must forfeit his personal interests in a situation such as the situation in which Winkelried had placed himself, the critical issue is whether or not this duty of integrity is enforceable. Without such enforceability, the conclusion must be that, here, the frontiers of the law's effectiveness have been reached. Analyzing the legal strategies described above, the conclusion must be that Winkelried cannot be forced to sign, as a person of integrity, the agreement required by Warren Buffet.

Nevertheless, the term integrity is widely used, which at least suggests legal enforceability of the term. A review of selected but representative corporate governance codes indicates that numerous jurisdictions have codes (and in the case of the US have federal regulation) containing a reference to 'integrity' as an obligation to be

8. If the agency theory is embraced, a list of legal strategies to monitor and control the agent is available. See Kraakman et al. 2011, p. 39, which is also illuminating for the listing of available legal strategies if the agency theory is not embraced. fulfilled to achieve good governance. ${ }^{9}$ Apparently, the rule makers assume that integrity is an obligation that can be imposed. How to enforce such an obligation is another matter, though; as noted above, the existing legal strategies appear to be incapable of doing so. It is therefore a matter of debate whether or not the term integrity can be maintained in legal regulation such as corporate governance codes as an unenforceable principle. The term should either be made operational so that it can be enforced or, if unenforceable and devoid of legal content, it should be left out of the legal legislative domain altogether.

Establishing whether or not the norm of integrity is observed is conditional on making behaviour transparent. The same is true in respect of other provisions contained in corporate governance codes. Transparency, in the sense of disclosure about behaviour, is therefore a key element for the overall practical relevance and functioning of these codes and especially required when addressing integrity.

The debate whether or not integrity could or should be maintained in legal regulation touches upon the scope and frontiers of the legal function as has been explored in legal theory. Resorting to the work of prominent legal theorists and philosophers, we have tried to find arguments to overcome this dilemma around 'integrity' posed by the apparent general acceptance of the norm in rules and regulations on the one hand and the unenforceability thereof on the other. The following sections address this unsatisfactory situation that the unenforceability of the norm of integrity in codes of governance has not prevented its almost universal inclusion in these codes and also represent an exploratory attempt to add legal content to the norm of integrity in order to render it legally enforceable. First, an attempt will be made to understand the possible implications of resorting to absolute norms such as 'justice' and 'integrity' by discussing the theories about justice as advanced by contemporary legal theorists. Second, and after having noted that such absolute normative concepts give rise to dilemmas of transforming norms into ethical and behavioural guidelines that can be enforced, an effort will be made to understand the theories advanced by Amartya Sen, which enable a more practical and topical approach of normative ideas. Further, and after having noted the practical limits of these theories, the notion of integrity is explored in an attempt to operationalize the term.

\subsection{Normative Aspects of the Law}

If there were an overarching legal norm of ultimate justice and the obligation of integrity would form part of such norm, then conformity to such a norm could be seen as a legal obligation. The theories of Dworkin are based on this concept of ultimate justice. Admired by many, he has explained that principles of ultimate jus-

9. The selection of corporate governance codes included 12 codes: the US (SOx), the UK, Germany, France, Italy, Japan, the BRIC countries, South Africa and the Netherlands. The codes of South Africa, India, Russia, the US, Japan, the UK and the Netherlands use 'integrity' in a normative sense. 
tice can be found via a 'one right answer' thesis. Such right answer can and will be found by judges, who, during their judicial deliberation, find these 'tacit' principles. ${ }^{10}$ According to Dworkin, ultimate justice does not rely on varying social factors but is based on legal principles which are "standards to be observed, not because it will advance or secure an economic, political, or social situation deemed desirable, but because it is a requirement of justice or fairness or some other dimension of morality". ${ }^{11}$ In this view, the law contains norms that are binding even though they have not been the subject of past social guidance. They are binding, rather, because of their moral content.

Dworkin's theory of justice has inspired many, and his theory and the possible practical applications thereof are not discussed here. In this article, we focus on the enforceability of a normative term, integrity, in times of crises and in particular in the context of Winkelried's refusal to sign the lock-up condition. Dworkin's approach could be described as 'transcendental' in the sense of a normative perfect ideal. Because of this transcendental nature, we initially hesitated to resort to his theories in our current endeavour to introduce a binding principle of integrity.

Hart's approach, on the other hand, is not based on a concept of ultimate justice. He finds that legality is determined by social practice rather than by morality. Justice can only be measured de facto via a 'rule of recognition', a social rule consisting of "a set of criteria by which officials determine which rules are, and which rules are not, part of the legal system". ${ }^{12}$ A legal system consists of a union of primary rules of obligation and secondary rules on how to change these primary rules. The rule of recognition is the most important secondary rule in Hart's 'rules approach'. This rule enables officials to find 'what counts as law' in a given legal system. The validity of these findings cannot be questioned if all the tests of the rule of recognition have been passed. Through the application of the rule of recognition, the authority and binding effect of the law so identified are given. ${ }^{13}$

Hart's approach qualifies as a positivist approach, i.e. a means to approach the non-binding principle of integrity in another way; it excludes the requirement of judicial deliberation as the only means of finding the 'right answer'. His rule of recognition approach is based on reality and has found its way into the public law of legal systems worldwide. Yet, Hart's approach does not facilitate our research to find means to overcome the abovementioned dilemma. Hart claims that the validity of the law found by the application of the rule of recognition cannot be questioned. This concept is based on a transcendental, non-empirically proven belief, which does not provide actual guidance to determine how to enforce the concept of integrity.

For another possible solution, we resorted to Rawls' theory of justice. ${ }^{14}$ From behind a 'veil of ignorance', principles of justice can be found. In order to overcome the ignorance, Rawls defines an 'original position'. ${ }^{15}$ This is a thought experiment in which participants are deemed to be participating in a position where they are equally constrained in their knowledge, motivations and tasks. In this position, the participants engage as rational contractors in a process granting equality to all participants of both basic liberties and equality of opportunity. These two central principles of justice, as defined by Rawls, regulate the basic structure of society. ${ }^{16} \mathrm{He}$ accepts that the distribution of basic liberties and the principle of equality of opportunity may nevertheless give rise to social and economic inequalities. These inequalities, however, are acceptable if they satisfy the condition that intervention, e.g. by the lawmaker or the judge, must be benefiting the worst-off rather than the best-off. ${ }^{17}$ This process of finding justice reflects an ultimate state of balance or coherence among a set of beliefs, resulting in finding justice. Rawls is convinced that democracy is the best - yet imperfect - system for procedural regulation of justice. In case democratic decisions 'breach' these principles of justice, Rawls sees civil disobedience as an allowed means to call upon the gut feeling of justice and start the public debate. ${ }^{18}$

Rawls' theory of justice as fairness is therefore also based on a transcendental idea, promoting the existence and feasibility of absolute justice. The contributions of Rawls to understanding the operation of justice, for this reason, cannot immediately be applied to the resolution of the abovementioned dilemma.

The classical theories of the law proposed by Dworkin, Hart and Rawls, by virtue of their positive reference to transcendental ideas, frustrate the practical development of a legally enforceable 'test' and definition of integrity. For that reason, an alternative theory of justice is now explored.

\subsection{Sen's Efforts to Escape 'Transcendental' Norms}

In the investigations, as shortly summarized above, useful arguments were found in the theories advanced by Amartya Sen. ${ }^{19}$ Accepting that fairness or justice defined as ultimate or unequivocal principles may prove to be unattainable ambitions, Sen concentrates not on justice but on injustice. Fairness is not referred to as a transcendental principle but is applied as a solution to clear injustice. Sen helps to understand why problems arise when applying transcendental principles to realworld situations. Sen addresses the reality of conflict
10. Dworkin 1986, p. 157. See also Peak 1998, pp. 24-26.

11. Dworkin 1986, p. 153.

12. Hart 1994, pp. 238-276. In Hart's theory, 'officials' are essentially government officials, whose behaviour is guided by the primary rules of the legal system and to whom the primary rules are addressed when changing primary rules. See also Bix 2009, p. 40.

13. Hart 1961, pp. 94 et seq.

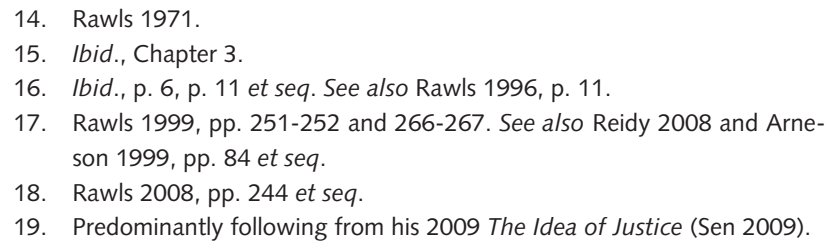


between social, human and other basic liberties and rights but does not seek to settle this conflict by reference to a 'higher principle' or other transcendental notions. ${ }^{20}$ A striking example of this method is a person buying a painting and having the choice between a Picasso and a Dalí. In order to make the 'right' choice, this person does not have to follow the definition of beauty, e.g. embodied by the Mona Lisa. ${ }^{21}$ Sen refers to Adam Smith, who also used a comparative, or relative, approach to achieve social fairness. Where Smith reverts to judgements or observations by an impartial spectator', 22 Sen emphasizes the comparative element in the decision-making process. The ultimate decisions reached are based on the outcome of the comparison and not on the conformity with transcendental principles. ${ }^{23}$ Sen challenges the theories assuming that a person can decide in accordance with 'absolute justice' after and because he has found such justice through empirical or other means. Absolute justice cannot be found. Instead, pure practical reason must be used to deal with famine, discrimination, women's rights or child labour. If those children or those women do not get a voice, injustice will persist.

Sen's theory also has topical application. On the one hand, he demonstrates that the abovementioned conflicts between social, human and other basic liberties and rights do, and may, exist and on the other hand that transcendental notions are not required to resolve these conflicts. As an example of conflicting principles, he mentions the parable of the three children and the flute. Suppose three children are quarrelling over a flute. Anna says she is the only one who can play the flute, so obviously we should give it to her. But then Bob says that he is the only child who has no toys at all, so surely he ought at least to have a flute to play with? Suddenly the question does not look so easy. And finally Carla points out that she spent months actually making the flute. So who should get it? In a perfectly just society, we would end up in an impasse. For Sen, though, any theory of justice must begin in recognition of such clashing principles. Sen, foreseeing that the flute cannot be split in three, promotes a comparative approach wherein the situations of Anna, Bob and Carla are compared and an ordering is made. This ordering is pluralistic because their arguments are equally valid. ${ }^{24}$ With this parable, Sen does not attempt to solve the question of who should get the flute, for justice can be found in a variety of approaches and many theories of justice of which none is the 'right' one. Instead, he seeks to illustrate the infeasibility of attempting to formulate the philosophical conditions of a perfectly just society. In order to demonstrate that justice can be achieved without transcendental notions, he refers to the abovementioned example where the 'absolute' beauty of the Mona

20. Sen 2009 , p. 9 , p. 15 , p. 101 . See also Gilabert 2012, p. 5.

21. Ibid., p. 16, pp. 101-102.

22. Smith 1759, pp. 129-135

23. Sen 2009, pp. ix-x. See also Chatterjee 2013, p. 124 et seq.

24. Confirming the 'futility of trying to achieve a perfectly just outcome', Chatterjee 2013, p. 124
Lisa is not required as a fundamental notion to determine which choice between Picasso and Dali is the best. ${ }^{25}$ Essential in Sen's comparative approach is the advancement of public debate. ${ }^{26}$ Comparisons are not feasible without information and human rights, especially freedom of speech, should be protected in order to give voice to the abovementioned problems of famine, discrimination, women's rights or child labour.

\subsection{From Normative to Operative}

We have found that the pre-eminent contemporary theories of justice, advanced by Dworkin, Hart and Rawls, have taken the 'transcendental institutional route'. Their theories have provided important insights into the demands of a 'just society' and share the common aim of identifying just rules and institutions. On the other hand, Smith's focus is on actual realizations and not on institutions and arrangements. He focuses on comparisons rather than on transcendence. Sen also follows a comparative approach in that he seeks to compare practical situations in society; the purpose is to tackle injustice rather than to achieve absolute justice. ${ }^{27}$ According to Sen, principles of absolute justice are not required to recognize basic injustice such as slavery or the subjugation of women. ${ }^{28}$ Since absolute justice does not exist in a comparative situation, neither does 'absolute solution'. Sen's approach recognizes the possible contradiction of legitimate interests while evaluating them against a pluralistic background.

Sen distances himself from transcendental notions of justice by shifting the paradigm to comparative judgement and social choice theory. Among his critics, Ingrid Robeyns refutes Sen's declaration of the redundancy of transcendental theories. In her view, and as opposed to the basic cases of injustice Sen uses as examples to support his theory, she holds that it is difficult to identify and analyze complex cases of injustice. According to Robeyns, the most effective way to argue the injustice of a complex case is to advocate principles of ideal justice, whilst empirically showing that these are not met. ${ }^{29}$ Further she holds that Sen's comparative approach also requires transcendental theories of justice in order to reach the most just situation possible in any given case. A mere comparison of two options may offer the most just outcome in the short run, but it may result in "a sub-optimal situation (from the point of view of justice) in the long run, due to the path-dependency of our actions". ${ }^{30}$ In other words, choosing the more just option today may bar access to an option that is even closer to complete justice tomorrow (e.g. short-term

25. Sen 2009, p. 16 , pp. 101-102.

26. Essentially given by the comparative model of Smith's impartial spectator, permitting open and open-ended discussion, hence the opportunity for people to revise their views based on their changing positions and changing information. Cf. Bird-Pollan 2010, p. 105 and Gaus 2012, p. 272. See also Satz 2012, p. 279, as well as Chatterjee 2011, pp. 199-215.

27. Cf. Sen 2009, p. ix.

28. Ibid., p. xi-xii.

29. Robeyns 2012, pp. 159-163.

30. Ibid., p. 162. 
decisions to resolve an acute problem of a demanding customer may have a negative impact on the long-term corporate interests). An ideal of justice would allow finding of the path to choose in order to reach optimal justice.

According to Sen, the debate on justice is of a theoretical nature. He observes that principles of perfect justice cannot be applied sec, as they bear little resemblance to 'real' situations and cases of injustice. We share Sen's view, yet keep in mind the arguments of his critics, arguing that in comparing complex situations the outcome will be based on a normative concept. This holds for theories of justice, but similar arguments can be advanced in respect of the term integrity.

Transcendental principles can only have a limited function or meaning when analyzing these principles in respect of the notion of integrity. In order to investigate whether or not the principle of integrity can be made legally enforceable, it is not realistically feasible to advance an all-encompassing theory on integrity comparable with the theories on justice as discussed above. Nevertheless, the fact that the notion of integrity is used in legal research and practice worldwide constitutes sufficient ground for a more topical approach.

We will attempt to undo integrity of its normative implications. Our efforts concentrate on - and are limited to - Jon Winkelried's behaviour, and we emphasize that there is no ambition to advance an overall theory for the improvement of corporate governance. Formulated in greater detail following our normative examination, this article will now examine the following question: do we have to accept classical legal strategies' inability to force Winkelried to sign the agreement offered by Warren Buffet? A further reservation is that we have assumed that Winkelried's refusal to sign and the reasons and circumstances underlying this refusal constitute a breach of integrity.

\section{Notion of Integrity in Corporate Law}

Despite national differences and varieties, the national corporate governance codes that have been issued in the last decades express significant similarities. A common understanding exists about the role that corporate governance plays in the modern company. These codes are based on the notion that good governance requires integrity and transparency. Transparency in this sense differs from the obligations of transparency prescribed by hard law, e.g. publication of documents such as a prospectus, an annual report and registration with the Chamber of Commerce. Transparency in codes of corporate governance is an operational requirement resulting from the normative principle of integrity. As corporate governance codes are generally in the form of soft law, also the principle of integrity, although of prime importance for good corporate governance, is by its nature not directly enforceable by applying the provisions contained in the codes. The same problem arises for the concomitant requirement of transparency, which cannot be directly enforced either due to the soft law nature of the governance codes. Principles and best practices other than integrity are generally enforceable only if they reflect or refine existing elements of hard law, or are to be seen as ancillary operational tools when applying provisions of hard law, such as statutory provisions regarding conflicts of interest or through contractual or similar arrangements. An example of the latter is the requirement that the provisions of the code must be applied as a condition for being listed on a stock exchange. Such means of (in)direct enforcement do not seem to be available in respect of the principle of integrity. In certain circumstances, however, there are instances which may lead to direct enforcement possibilities. This is the case if acting against the norms of integrity and transparency is tantamount to infringement of a general norm of good faith, reasonableness or another similar general norm incorporated as a hard law rule in almost all jurisdictions. The necessary interpretation and 'colouring' of the norm of integrity through jurisprudence and legal research - as has happened with the norm of good faith and reasonableness - is, however, still missing. As held supra, ${ }^{31}$ it is assumed that Jon Winkelried's initial refusal to sign the lock-up agreement required by Warren Buffet constituted a violation of the norm of integrity without the possibility of sanctioning such behaviour through the use of legal strategies for direct enforcement.

\subsection{Integrity in the Codes}

With the wave of impressive corporate financial scandals of the 1980s and 1990s, corporate governance codes were designated as a response to encourage company managers, shareholders, stakeholders and controlling agencies to mind their corporate etiquette in order to prevent - or, at least lessen the impact of - such scandals in the future. Additionally, corporate governance codes were amended and introduced to restore trust in the financial markets and the economic system in general as a response to new scandals, governance failures and the financial and subsequent economic crises that commenced in 2007. Next to being a governance road book for company boards, these codes are also a reflection of the lessons learned from these scandals, failures and crises.

In previous research, the assumption that the principle of integrity as reflected in corporate governance codes is not directly or indirectly enforceable is verified by inspecting the OECD Principles of Corporate Governance, as well as 19 national corporate governance codes. ${ }^{32}$ Empirical research into the corporate governance codes in a wide variety of countries provided a description of the generalities and commonalities forming the basis of national codes of corporate governance

31. Paragraph 3.

32. Steins Bisschop \& Römkens 2014. 
and in particular presented a picture that reflects as much as possible the general and global trends in approaching the principles of integrity and transparency. The selection of the countries under review enabled a global, representative view on the concepts of integrity and transparency as referred to in the national codes. The 19 jurisdictions were chosen for the following reasons: the US, the UK, France, Germany, Italy and Japan were chosen following the selection of these countries in the book The Anatomy of Corporate Lam. ${ }^{33}$ The Netherlands was added as it is the home jurisdiction of the authors. Brazil, Russia, India, China and South Africa were discussed as countries identified as emerging economies and referred to as 'BRICS'. Turkey, Indonesia, Vietnam, South Korea, the Philippines and Pakistan were discussed as jurisdictions representing emerging economies. Finally, Mexico was discussed as, next to Brazil, it is a powerful economy in Latin America.

The results of this empirical research provide an indication of the global representative view on the concepts of integrity as referred to in the national codes, from which general conclusions may be drawn. The majority of the corporate governance codes of these 19 individual jurisdictions contain direct references to the principle of integrity. The fact that some of these codes do not contain direct or literal references to this principle ${ }^{34}$ does not negate the fact that a notion similar to the term integrity forms part of the concept of good governance in such jurisdictions, with integrity as an important tool for improving and fostering good governance. The preambles and explanatory provisions regarding the backgrounds and purposes of the codes in combination with a reference to general norms of good faith, reasonableness or another similar general norms incorporated as a hard law rule in almost all jurisdictions confirm the indication that such 'soft' norms indeed form a universal basis for good governance.

At the same time, the review of the codes in these 19 jurisdictions indicates that the principle of integrity, despite its apparent importance in the selected jurisdictions, cannot be enforced using the legal strategies currently provided by law. This non-enforceability appears therefore to pose a global problem that, if resolved, could cause a shift in thinking about the legal status and enforceability of corporate governance codes in general.

\subsection{Integrity as a Legal Notion}

None of the national corporate governance codes discussed above appear to have a hard law or equivalent enforcement mechanism in place for enforcing either the principle of integrity or the consequential operational requirement of transparency. ${ }^{35}$ Instead, 'comply or explain', 'apply or explain' or 'comply or else' are means of enforcement based on the belief that companies will

33. Kraakman et al. 2011

34. See the codes of France, Germany, Italy, Turkey, Vietnam and Mexico.

35. Unless 'integrity' is tantamount to 'good faith' as a global notion in hard law, which - contrary to integrity - is made enforceable through case law and legal comments. See following paragraph. comply with the soft law provisions in the code. The significance of these principles, though differing from country to country, is emphasized by the general and global reference thereto in the text of the codes. Adherence to these principles is apparently considered to be of fundamental importance for good corporate governance. These principles are nevertheless left without legal means of direct or indirect enforcement.

There is a marked inconsistency between, on the one hand, requiring integrity as condition for good governance and, on the other hand, providing no possibilities to enforce such a norm. There are ample reasons to advance good governance through enforceable legal means or strategies. The recent subprime mortgage crisis, preceded by corporate failures in the last four decades and followed by the credit crunch and global financial economic crisis, underpins the urgency to improve corporate governance.

Does this mean that we should conclude that good governance cannot be based on a legal principle of integrity supported by transparency? Perhaps not. From a statutory or regulatory point of view, two options remain: either these principles should then be left out of the codes or they should be rendered enforceable by means of a novel and revised interpretation of their legal content and force. The following paragraphs represent an effort to achieve the latter.

\subsection{A Sustainable Corporate Model}

In order to understand further the notion and concept of integrity in the context of corporate governance codes and the rights and obligations of those who are responsible for good corporate governance, it is useful to also explore the purpose of the company and the position of the variety of its stakeholders. It appears that there is a certain tendency towards convergence of the existing concepts of the corporate model.

The recent crises and failures, referred to above, took place in a corporate environment. This observation invites a discussion on whether or not the corporate form of engaging in business should be fundamentally changed. We hold that there are no reasons to change the present global model of conducting business in the form of companies financed by share capital. This view is briefly elaborated as follows.

The corporate business model was developed in the 17 th century by separating the entrepreneurial activities of an enterprise from its financing: an 'act of magic' that gave 'life' to a separate, independent entity with legal personality, allowing the newborn company to engage in contracts and do business in its own name. ${ }^{36}$ The VOC was the first institutionalized trading company resembling today's multinationals, with the corporate interest to secure a trading monopoly in spices from the East. ${ }^{37}$ The magic rests in the separation between the direction and the ownership (control) of the company - resulting in a division of powers, rights, interests and entitle-

36. See Faure \& van der Walt 2010, pp. 211-254.

37. Ibid., p. 213. 
ments. Whereas the company was governed and controlled by its directors, it was the supply of share capital that allowed for investments and growth of the enterprise. The investors provided the capital while at the same time enjoying limited liability and a share in the company's profit. Since shares in the company could be sold freely without the involvement of the corporation itself, liquidity was continuous for the company as well as for its investors.

The corporate organizational structure of contemporary companies largely matches that of the companies that were firstly incorporated in the 17 th century. The key characteristics of the modern company are legal personality, limited liability, delegated management under a board structure, transferable shares and investor ownership. ${ }^{38}$ These elements also characterized the VOC following its incorporation in 1602. Due to their investment and shareholding in the company, the shareholders in general meeting were granted the power to appoint and dismiss management, to adopt the annual accounts, to decide on matters relating to the capital of the company and to decide on the corporate statute and liquidation. In the 21 st century company law, these powers are based on the DNA of 17 th century companies and are the fundamental general meeting's exclusive rights.

The modern global corporate structure provides for sufficient checks and balances to advance good corporate governance. Good governance of companies worldwide requires taking into account the interests of all company stakeholders. Notwithstanding the different concepts on how the goal of serving the interests of a wide range of stakeholders should be attained, a convergence of theories appears to lead the way to a univocal concept of good governance wherein management is required to have due regard to the interests of all company stakeholders.

\subsection{Shareholder Interest}

The stark distinction between the shareholder and stakeholder models in corporate governance, as maintained in legal theory, is contradicted in practice where companies are generally seen as independent entities, striving to maintain the continuity of business in the interests of all stakeholders without allowing either stakeholder's interests to dominate.

Both the shareholder and stakeholder theory and many other theories - including corporate social responsibility - regarding the corporate anatomy are normative theories, proposing what a company's role should be. As such, these theories have a view on how managers should take decisions in the 'right' way. Although there are many different models and theories of corporate governance, only some aspects are discussed, which could be relevant or helpful in determining the meaning and relevance of integrity in the corporate context. The reconsideration of the various theories and concepts regarding the corporate model and organization appears to point at a general concept that companies are to be governed in the interest of a wide range of stakeholders. Very briefly summarized, the shareholder theory considers managers to be primarily, if not exclusively, responsible for maximizing shareholder returns. As Milton Friedman wrote, "There is one and only one social responsibility of business - to use its resources and engage in activities designed to increase its profits so long as it $[\ldots]$ engages in open and free competition, without deception or fraud". 39 The shareholders have to advance capital to the company's managers who in turn are supposed to spend corporate funds only in ways that advance the shareholders' financial interests.

An element of the stakeholder theory is that it requires managers to balance shareholder (financial) interests against the interests of other stakeholders such as employees, customers, the environment and even society at large in order to safeguard the company's continuity. Accordingly, managers must act as agents of all stakeholders, not only the company's shareholders.

The fundamental distinction between both theories is the goal of the company. Whereas shareholder theory endeavours to maximize returns for a company's shareholders, stakeholder theory requires consideration of the interests of all stakeholders without focusing solely on the interests of one corporate constituency.

Unlike the shareholder theory, the stewardship theory is seen as an alternative to the agency theory, the latter of which assumes that managers act in their own interests unless appropriate governance structures are implemented. Stewardship theory assumes that managers, instead of being opportunists, allow the interests of the collective organization to prevail. It sees no inherent general problem of executive motivation; it therefore questions the dominance of the agency theory as a basis of many corporate governance systems worldwide. Following stewardship theory, there is no need to discipline managers, since managers and shareholders are assumed to have aligned interests. In this concept, stewardship in corporate governance is about well-chosen engagement instead of just voting in order to act as a steward. ${ }^{40}$ The stewardship theory will be referred to further below when discussing the shareholdings of institutional investors.

In s.172(1) of the 2006 Companies Act, the UK has codified the enlightened shareholder value approach, providing that "a director of a company must act in the way he considers, in good faith, would be most likely to promote the success of the company for the benefit of its members as a whole". In doing so, a director must have regard to a (non-exhaustive) list of factors, unrelated to direct shareholders' interests and including "the likely consequences of any decision in the long term, the interests of the company's employees, the impact of the company's operations on the community and the environ- 
ment" and "the desirability of the company maintaining a reputation for high standards of business conduct". ${ }^{41}$ The enlightened approach emphasizes long-term strategy prevailing over short-term interests. It underlines the company's long-term sustainable growth and requires directors to also take into account a wider range of non-shareholder interests. ${ }^{42}$ Since s. 172(1) Companies Act 2006 does not offer stakeholders any means to enforce any directors' enlightened duty, the effectiveness of the provision can be questioned. ${ }^{43}$ Nevertheless, the fact that the new regime allows a broader range of claims to be brought could imply that employees with a shareholding in the company could decide to bring an action against the directors for breach of their duty of loyalty under s. 172(1). This would represent a step towards convergence to the continental European corporate governance model.

\subsection{Convergence}

The recent developments on the capital markets also contribute to the process of convergence of the various concepts of corporate organization. The integration of financial markets on an international level is a dynamic force in the globalization process of national corporate governance institutions. The increase in institutional shareholdings on a global scale could be seen as an indicator for convergence of corporate governance systems or at least as a facilitator for cross-border activity on a global scale. ${ }^{44}$ New financial instruments and deeper integration of markets have forced (larger) enterprises to rethink their way of doing business and adapt their governance strategies. In this way, the trend towards convergence of corporate governance regimes has already been set, due to the pressure experienced by firms to adapt and compete with foreign firms amid growing international competition. A de facto convergence of cost structures and firm organization has the effect of spilling over to a convergence of firm behaviour and decision-making processes.

As a result, the difference between the Anglo-Saxon and continental European approach in corporate governance and company law is becoming less important as well. The fact that securities regulation - impossible for companies to opt out of - applies to a large segment of the corporate sector and is similar in common law as well as civil law countries illustrates the lessened importance of this once 'great divide' in perceptions about the corporate goal and interest. ${ }^{45}$

The primary responsibility for corporate governance in publicly listed companies lies with the company's board in overseeing the actions of management. Following the agency theory, managerial opportunism needs to be forestalled by introducing specific mechanisms that

41. UK Companies Act 2006, s. 172(1)(a-f).

42. This approach is not new, though. In the US, constituency statutes allow company directors to consider the interests of stakeholders (other than shareholders) as well as the long-term interests of the corporation.

43. Cf. s. 260(1, 3) CA 2006. See also Marshall \& Ramsay 2009.

44. Davis \& Marquis 2005.

45. Nestor \& Thompson 2001. reduce agency costs. Incentive schemes are set up to reward managers, the agents, for maximizing shareholder interests. Corporate financial scandals in the past led to more rules and more rights for shareholders to use their shareholding to improve how their company would operate on the market. In this regard, the importance of the role of institutional investors in monitoring and 'disciplining' large international companies has grown rapidly. They need to hold the board to account for fulfilling its responsibilities through monitoring and engagement in e.g. the company's strategy, performance and corporate governance. Taking the UK Stewardship Code as an example, institutional investors were called upon to exercise their shareholder rights in a responsible manner through well-chosen engagement, purposeful dialogue and by casting informed votes. ${ }^{46}$ This concept or interpretation of the roles and responsibilities of institutional investors resembles the fundamentals of the stewardship theory. Managers are considered under this theory to be non-opportunistic, 'good stewards' of the corporate assets, essentially striving to do a good job for the company as a whole. In doing so, the manager depends for her success on the surrounding framework within which she has to operate: the company's organizational structure. As such, the company as a whole becomes responsible for guaranteeing managerial 'wellbeing' and good performance. The institutional investor stewardship concept is based on the premise that 'a new breed of highly skilled and well-resourced professional shareholders would make informed use of their rights, promoting good corporate governance in companies in which they invest' ${ }^{47}$ Whilst the increased percentages of shareholdings by institutional investors would allow for the effective control and disciplining action by these investors, it appears that they do not make full use of these possibilities for a variety of reasons. One of these reasons is that institutional shareholders tend to spread their investments in more companies resulting in relatively lower percentages of shareholding in more companies. Already for practical reasons, it becomes increasingly difficult for institutional investors to behave as engaged shareholders, actively using their controlling rights to advance and achieve good corporate governance. Another aspect diluting the role and disciplining duty of institutional investors is that they themselves are actually not under control by their stakeholders. ${ }^{48}$

In the convergence debate, Lynn Stout takes the view that stakeholder theory misses one important point. Whereas it is the goal of the company's management to consider the interests of shareholders as well as those of - i.a. - employees, consumers and society as a whole, it is often unclear how managers are supposed to balance these stakes. Furthermore, how can the performance of management be measured, when it is logically or practi-

\footnotetext{
46. Melis 2014, pp. 1-2.

47. OECD 2012, p. 9.

48. Melis 2014.
} 
cally impossible to maximize value in more than one dimension at the same time? ${ }^{49}$

Stout argues that shareholder theory is the better of two bad choices but serves only a limited purpose in terms of holding management responsible. As opposed to stakeholder value-oriented companies, by using stock price as a measure for management performance, companies acting in line with shareholder theory are able to keep agency costs at a minimum. One would therefore expect shareholder primacy to be dominant in practice. Empirical evidence proves otherwise, following Stout. Examining lawmakers, judges, companies and shareholders, she concludes that stakeholder theory is favoured in practice. Lawmakers have passed laws that allow boards to sacrifice the interests of shareholders for the benefit of other stakeholders; case law suggests that Delaware judges generally favour the stakeholder model; companies avoid incorporating in states with a strong bias for shareholder primacy, and shareholders do not promote shareholder primacy through charters and bylaw provisions. ${ }^{50}$ Stout concludes that shareholders prefer stakeholder primacy even though shareholder primacy would be theoretically more efficient in reducing agency costs. ${ }^{51}$

The upshot of discussing the various models is that it has revealed a tendency towards using the stakeholder model, with an important role being played by the shareholder model performance metric, stock price. The result of this tendency is different from the enlightened shareholder model in the sense that the latter still places shareholders at the centre stage, while the former takes all stakeholders as starting point. This could be interpreted as a convergence between the shareholder and the stakeholder model, resulting in a stakeholder model in which management performance is measured using stock price.

As a result of the discussion on corporate models, the form that the principle of integrity must take becomes clearer. The stakeholder model with stock price performance measurement provides managers with a behavioural compass which points to integrity. In other words, behaving with integrity will be within the limits set by the aforementioned corporate model.

Another aspect providing understanding of the roles and responsibilities in the governance debate is related to legal personality. Companies are to be considered as persons under the fiction of the law. A natural person is not owned by anyone, is the owner of her properties and obligated to fulfil contractual and other obligations. In order to secure these rights and to protect persons as citizens against stately breaches of their integrity, they can invoke national and international provisions of human rights. Semantically, it could be argued that companies as legal persons could invoke human rights. It appears that in case law and legal literature, legal per-

\footnotetext{
49. Jensen 2002, p. 238.

50. Stout 2001, pp. 1201-1208.

51. Ibid., p. 1202.
}

sons indeed are entitled to invoke the protection of human rights. ${ }^{52}$

As a human right, the protection of personal integrity is often viewed as one of the most fundamental human rights. Generally, personal integrity can be defined as the right to life and liberty which in practice is interpreted as the right of any natural person to be protected against unlawful state-imposed deprivations of life, physical harm at the hands of state agents and stateimposed detention. ${ }^{53}$ When discussing whether or not companies are protected on the same basis or on a similar basis, it should be observed that it is unclear what this right of personal integrity entails when applied to companies (e.g. in case of a hostile takeover).

Companies can claim the applicability of human rights. When incorporated, companies are considered to be persons in the legal sense with their own nationality and applicable law. This status of being a 'legal person' enables companies to e.g. enter into contracts and own property. Furthermore, they can use this status in order to effectively claim human rights. An example is the situation of a hostile takeover attempt that is resisted by management on the ground that the bidder has declared that the company shall be stripped from its assets and liquidated for opportunistic purposes. In this situation, it is conceivable that the company invoke the protection of the first protocol to the European Convention on Human Rights. ${ }^{54}$ Another example is related to the freedom of speech. ${ }^{55}$ The word 'everyone' is found throughout the whole of the Universal Declaration of Human Rights and the European Convention on Human Rights, and as it includes more than just human beings, companies are covered by these provisions as well.

Goldman Sachs as a company has a right to be protected against infringement of its personal integrity. In casu, it could be argued that Winkelried not signing the lock-up agreement would have automatically meant the demise of Goldman Sachs. Therefore, the existence as well as the continuity of the corporation is a right that needs to be respected and can be enforced by Goldman Sachs, even against its shareholders.

Not only the views on the corporate model and organization, but also the discussion on the applicability of human rights protection available to the company as a legal person, contribute to the understanding of the meaning of the term integrity as appearing in the majority of corporate governance codes. For the purpose of this article, integrity is understood to constitute a global principle that is conditional for good governance. The dilemma is, however, that this function may globally be recognized and mentioned in regulation but appears not to be generally enforceable.

If a term or concept is deemed relevant in the legal sense but lacks enforceability, it is justified to conclude that

52. Steins Bisschop 2008. See also Timmerman 2006, pp. 23-32.

53. Cf. Hill 2013.

54. See i.a. Société Colas and others v. France, no. 37971/97, EHCR 2002II.

55. Cf. Krzemińska 2005. 
questions with respect to the observance of such a principle are not a legal matter. Such a conclusion could give rise to the argument that the reference to integrity be removed from the provisions of the codes.

In the following paragraphs, we will investigate whether the term integrity could be 'translated' into another term which is both enforceable and able to contribute to the function that the global term integrity apparently has as contained in the various codes and against the backgrounds of the corporate organization.

\section{9 'Translation' of the Norm}

Integrity is a container term covering a much wider variety of norms than only the norm that the law must be observed. It is an indication of the norms, values and culture that exist both in the specific corporate context and in the social surroundings which must be respected. Many companies are able to specifically define their corporate culture based on these norms. Nevertheless, these normative principles, if regulated at all and even if detailed, form 'soft' rules. Decent business persons must be persons of integrity, but contrary behaviour not simultaneously being an infringement of a hard law obligation cannot be sanctioned.

One of the many examples of such un-sanctionable behaviour is found in the rewards that were received by the CEO and senior management of ABN Amro Bank in 2007. The executive board was held responsible for the disappointing results, especially in the years following the appointment of the CEO in 2000. The CEO had issued ambitions and reassuring statements about the company's growth and competitive position. The very ambitious plans failed to be realized for a number of reasons including unsuccessful acquisitions and poor governance. This resulted in relatively low stock prices that made the company vulnerable for a takeover. When this takeover actually occurred, the $\mathrm{CEO}$ and a great number of senior bank employees who had received share options were confronted with the situation that their options which, after having lost their value due to underperformance, suddenly regained their value. This was seen as a reward for failing management. However, attempts to prevent exercise of these 'rewards for underperformance' or to achieve claw backs were unsuccessful. It should be noted that the entitlements of the senior executives of ABN Amro were all based on contracts. There were hard law arguments to counter the attempts to deny the executives the benefit of these contracts. This is different in the case presented at the beginning of this article regarding the high rewards for Jon Winkelried and the question whether or not he was legally obligated to sign the lock-up agreement as justifiably required by Warren Buffet. Not his remuneration package as such, but the obligations stemming therefrom form the pinnacle of the discussion. Against this background, we have assumed that there were no legal strategies to force Winkelried to sign the lock-up agree- ment as required by Warren Buffet and that this was the reason for Goldman Sachs to assist Winkelried in overcoming his liquidity problems.

Another aspect to be noted in this respect is that the financial assistance provided by Goldman Sachs to Winkelried in fact constituted financial assistance by the bank for the purpose of raising equity. One of the fundamentals of corporate law is, however, that equity as risk capital is provided entirely at the risk of the contributor of the capital and without financial assistance by the company itself. Financial assistance by the company to such transactions would dilute this risk element as the company then participated in the capital contribution and shared in the risk of capital contribution. At the moment of the contemplated investment by Warren Buffet in the form of a capital contribution of $\$ 5$ billion, however, the greater interest of Goldman Sachs was its survival, and the financial assistance to Winkelried was in that respect a relatively minor issue. Even if the board of Goldman Sachs was aware of the legal objections against financial assistance to the acquisition of equity in general and had realized that they were confronted with the dilemma of strictly observing these legal provisions or choosing a practical solution, it is understandable that Goldman Sachs decided to provide financial assistance to the capital contribution by Warren Buffet by facilitating the resolution of Winkelried's liquidity problems. The justification of the bank's decision to provide financial assistance in the given situation does not take away that the underlying dilemma was caused by non-integrity on the side of Winkelried who had apparently invested his high rewards for total dedication to the company's interests in such a manner that he could not serve these interests at the moment this was most needed.

It is also acceptable on other grounds to assume that Winkelried's initial refusal to sign the lock-up agreement is contrary to the norm of integrity. His high rewards could not be based on any other consideration than that his functioning as board member added substantial value to the company. However, at the moment that he was requested to serve a vital interest of the company, signing a document securing the bank's survival of the immediately threatening failure, he could not oblige because of personal interests, namely a liquidity problem caused by a setback in his personal investments.

In this context, we have noted above that integrity and the consequential operational requirement of transparency feature as fundamental principles of corporate governance in most corporate governance codes worldwide in most cases, however, without means of enforcement. The challenge is whether or not this fundamental principle can be brought within the realm of enforceable law and be interpreted in such a manner that enforceability of the general principle can be created by the use of a more operational term. Such a term on the one hand redefines the norm to become a more positive as well as measurable and enforceable obligation but on the other hand does not deprive the container term from its gen- 
eral meaning and relevance as intended to be reflected in the governance codes.

The observations above about the notion of integrity in the context of recent crises, corporate governance codes, theories about corporate organization, the constitutionalization of corporate law and the corporate interest serve as backgrounds against which integrity, redefined as an enforceable term, can serve as an enforceable obligation against which behaviour may be tested.

Inspiration for such a concept of integrity can be found in the theory developed by Erhard and Jensen. ${ }^{56}$ In this view, an enforceable interpretation of the term integrity and its underlying principle can be achieved by reducing the normative aspects of the term. Integrity is made tangible by replacing it with another denomination. This reclassification must necessarily avoid dilution of the general meaning and relevance of integrity and, at the same time, provide for enforceability.

If the term integrity is replaced by the concept that promotes good governance, then this requires that those responsible are transparent in respect of what ex ante can be expected from them and ex post what they have achieved in realizing what they have promised to do. This concept requires that those responsible give their word in a transparent fashion and are held accountable in respect of the extent to which they have kept their given word. Such a given word then stands for moral, ethical and legal standards. Should a situation occur that a given word cannot be kept, this must be made public instantly. At that moment, an obligation arises that a given word must be honoured. Honouring a given word is an obligation that is not subject to bargaining or mitigation. Breaking a given word gives rise to mandatory action or obligation, in whatever form, to repair the damage caused by the broken word. In the modern corporate governance debate, this concept can well be used to further refine what constitutes good governance and to define the obligations of the board and its individual members. Managerial behaviour can be tested and sanctioned if necessary.

By interpreting integrity as giving, keeping and if necessary honouring one's word, the normative term, as found universally in codes of corporate governance, becomes a positive one. It contains a description of a concrete obligation against which actual behaviour can be tested. Sen's critique of the transcendental nature of norms does not apply to this definition of integrity. The obligations resulting from a mandatorily given word form a practical prescription of how one should act. They do not fall within the moral obligations which are marked by Sen as transcendental and therefore unattainable. The redefined term of integrity comes close to how Hart, Rawls and Dworkin envisaged attaining justice. They held that by formulating the perfect principle - which Sen denounced as being transcendental - the right way to act could be derived. The operational concept of giving, keeping and honouring a word also encapsulates a norm. This norm is, however, more tan-

56. Erhard et al. 2014, p. 5 gible than the norm in the term of the principle integrity'. The result of that redefining of the principle is an enforceable definition of integrity that will now be used to test Jon Winkelried's actions.

\section{Testing Jon Winkelried's Behaviour}

To assess whether Jon Winkelried's behaviour constitutes a breach of integrity as defined above, the reasons for his initial refusal to sign the lock-up agreement, are analyzed. The first observation is that his total income in 2006 amounted to $\$ 51.1$ million and for $2007 \$ 71.5$ million.

Such a high level of compensation earned by Winkelried should be regarded as a reward for total, efficient, unique and highest level dedication and commitment to the interests of the company, its shareholders and other stakeholders. At the moment, however, that the continued existence of Goldman Sachs was threatened by a bank run and subsequent failure, it appeared that Jon Winkelried faced a distinct disincentive for reaching this goal of total dedication. The incentive offered by his high earnings perverted into a case of moral hazard: the person taking the risk, Winkelried, is different from the one bearing the burden of that risk - in this case, Goldman Sachs.

The risk Jon Winkelried took was to invest his earnings in high-risk private investments (i.a. real estate and horse farms). These investments must have required active management and supervision, which also resulted in a risk for Goldman Sachs.

The risk on the shoulders of Goldman Sachs was the lack of total dedication portrayed by Jon Winkelried, which led to his initial refusal to sign the lock-up agreement. As a result, Goldman Sachs was forced to provide Jon Winkelried with financial assistance to solve his liquidity problem. While this form of 'incest finance' did solve the problem, the solution was not provided by the party taking the risk but by the party who was negatively affected when the risk materialized. This underpins that a situation of moral hazard occurred. This situation was exacerbated by the high reward that Jon Winkelried received. With his compensation rising, Winkelried's private investments would grow, along with the required attention of governing those investments. Consequently, the incentive for complete dedication to the interests of the bank and its stakeholders decreased as his compensation rose.

As a result, Jon Winkelried was unavailable when Goldman Sachs needed him. Failing to keep his implicitly given word of total dedication, Winkelried should have honoured his word by dealing with the consequences. One of the elements of the enforceable concept of integrity is that the consequences of a broken word and in particular the obligation to honour a given word cannot be mitigated. The obligation of integrity redefined as an 
obligation to keep and honour a given word would enable to repair the breach of integrity by Winkelried because he broke his implicitly given word. His 'liquidity problem' could not mitigate the consequential necessity to honour this given word by signing the lock-up agreement irrespective of the personal consequences and even when this would result in his personal bankruptcy. Adding this redefined concept of integrity, or even replacing the term with the obligation to keep and honour a given word, together with the obligation regarding consequential operational transparency, could resolve the problem caused by the unenforceable obligation of integrity as a condition of good corporate governance.

\section{Conclusion}

In this article, the notion of integrity as a requirement for good corporate governance is analyzed through a case study of the behaviour of Jon Winkelried.

Winkelried acted against his implicitly given word of total dedication. This obligation of total dedication should have resulted in doing what the survival of the company required, i.e. signing the essential lock-up agreement as reasonably required by Warren Buffet. The reason for not signing as given by Winkelried was his personal liquidity position. The liquidity problem was caused by negative developments in the high-risk investments of the very high income he had received in the previous years of his employment by Goldman Sachs. When asked to sign the lock-up agreement, Winkelried broke his word of total dedication which should have resulted in an obligation to honour his word and the obligation stemming therefrom and to sign the agreement, irrespective of the consequences. This obligation could not be enforced on the basis of the classic legal strategies but could be deemed enforceable if integrity were translated into an obligation to honour a given word. This latter obligation is enforceable and cannot be mitigated. A threatening personal bankruptcy of Winkelried could then not be advanced as an excuse for not signing. This solution would have avoided the necessity of Goldman Sachs to resort to an alternative solution of the problem by advancing financing to Winkelried which is contrary to the rule of prohibition of financial assistance by the company when raising equity. The proposal to overcome the un-enforceability of the normative term 'integrity' by focusing on a positive rule rather than a normative concept was made in the specific context of a concrete case. It was argued that in this case, Winkelried's initial refusal to sign the lock-up agreement constituted a breach of integrity defined as a norm contained in the legal environment and also that this breach could not be sanctioned by using the classical legal strategies. The redefined concept of integrity as the obligation to honour a given word after it was broken provided a solution for the problem of unenforceability of the norm of integrity as contained in present regulation.
This proposal was made against the background of corporate governance codes, theories and concepts of law, converging concepts of corporate organization and the corporate interest and the constitutionalization of corporate law.

This case-specific approach of efforts to convert the concept of integrity into an operational and enforceable legal instrument could possibly, and also more in general, serve as guidance to find broader understanding of the role currently played by the unenforceable principle of integrity and similar normative terms in corporate governance regulation and could aid in the debate on furthering good corporate governance through enforceable legal strategies. ${ }^{57}$

\section{Bibliography}

R.J. Arneson, "Against Rawlsian Equality of Opportunity", 93 Philosophical Studies 1, 1999, pp. 77-112.

L.A. Bebchuk \& R.J. Jr. Jackson, "Shining Light on Corporate Political Spending", 101 The Georgetomn Law Fournal 4, 2013, pp. 923-967.

S. Bird-Pollan, "Book Reviews: Amartya Sen, The Idea of Justice”, 2 Public Reason 2, 2010.

B. Bix, Furisprudence: Theory and Context, 5th edn, London, Sweet \& Maxwell, 2009.

D. Chatterjee, "Reciprocity, Closed-Impartiality, and National Borders: Framing (and Extending) the Debate on Global Justice", 27 Social Philosophy Today, 2011, pp. 199-215.

D. Chatterjee, "Building Common Ground: Going Beyond the Liberal Conundrum", 27 Ethics $\mathbb{E}$ International Affairs 2, 2013, pp. 119-127.

T. Clarke, "Corporate Governance Causes of the Global Financial Crisis", in W. Sun, J. Stewart \& D. Pollard (eds.), Corporate Governance and the Global Financial Crisis. International Perspectives, Cambridge, Cambridge University Press, 2011, pp. 28-49.

G.F. Davis \& C. Marquis, "The Globalization of Stock Markets and Convergence in Corporate Governance." in R. Swedberg $\&$ V. Nee (eds.), The Economic Sociology of Capitalism, Princeton, Princeton University Press, 2005, pp. 352-390.

R. Dworkin, Law's Empire, Cambridge, MA, The Belknap Press of Harvard University Press, 1986.

W. Erhard, M.C. Jensen \& S. Zaffron, "Integrity: A Positive Model that Incorporates the Normative Phenomena of Morality, Ethics, and Legality", 2014. Available at <http://ssrn. $\mathrm{com} /$ abstract $=1542759>$.

M. Faure \& A. van der Walt (eds.), Globalization and Private Law, Cheltenham, UK, Edward Elgar, 2010.

M. Friedman, Capitalism and Freedom, Chicago, University of Chicago Press, 1962.

G. Gaus, "Social Contract and Social Choice", 43 Rutgers Lam Journal, 2012, pp. 243-276.

P. Gilabert, "Comparative Assessments of Justice, Political Feasibility, and Ideal Theory", 15 Ethical Theory E Moral Practice 1, 2012, pp. 39-56.

H.L.A. Hart, The Concept of Lam, Oxford University Press, 1961.

H.L.A. Hart, The Concept of Lam, 2nd edn, Oxford University Press, 1994.

D.W. Hill, "The Concept of Personal Integrity Rights in Empirical Research", 2013. Available at <http://myweb.fsu.edu/ dwh06c/pages/documents/pi_concept13Aug13.pdf $>$.

57. For inspiration, reference is made to Bebchuk \& Jackson 2013. 
M.C. Jensen, "Value Maximization, Stakeholder Theory, and the Corporate Objective Function", 12 Business Ethics Quarterly 2, 2002, pp. 235-256.

R. Kraakman, J. Armour, P. Davies, L. Enriques, H. Hansmann, G. Hertig, K. Hopt, H. Kanda \& E. Rock, The Anatomy of Corporate Law. A Comparative and Functional Approach, 2nd edn, Oxford, University Press, 2011.

J. Krzemińska, "Freedom of Commercial Speech in Europe", Zentrum für Europäische Rechtspolitik Universität Bremen, 2005.

S. Marshall \& I. Ramsay, "Shareholders and Directors' Duties: Law, Theory and Evidence”, 411 Melbourne Law School Legal Studies Research Paper, 2009.

L.G. McDonald \& P. Robinson, A Colossal Failure of Common Sense: The Incredible Inside Story about the Collapse of Lehman Brothers, New York, Crown Business, a division of Random House Inc., 2009.

D. Melis, "The Institutional Investor Stewardship Myth. A Theoretical, Legal and Empirical Analysis of Prescribed Institutional Investor Stewardship in a Dutch context. Summary of Dissertation", 2014.

S. Nestor \& J.K. Thompson, "Corporate Governance Patterns in OECD Economies: Is Convergence Under Way?”, in Corporate Governance Corporate Governance in Asia. A Comparative Perspective, OECD Publishing, 2001.

Organisation for Economic Co-operation and Development (OECD), The Role of Institutional Investors in Promoting Good Corporate Governance, 2012.

I.H. Jr Peak, "Dworkin and Hart on 'The Law': A Polanyian Reconsideration", 1998. Available at <www.missouriwestern. edu/orgs/polanyi/TAD\%20WEB\%20ARCHIVE/TAD18 -2/TAD18-2-fnl-pg22-32-pdf.pdf>.

J. Rawls, A Theory of Fustice, Cambridge, MA, The Belknap Press of Harvard University Press, 1971.

J. Rawls, Political Liberalism, Columbia, University Press, 1996.

J. Rawls, A Theory of Fustice: Revised Edition, Cambridge, The Belknap Press of Harvard University Press, 1999.

J. Rawls, "The Justification of Civil Disobedience", in A. Kavanagh \& J. Oberdiek (eds.), Arguing about Law, London, Routledge Books, 2008.

D.A. Reidy, fohn Ramls, 2008. Available at <http://ssrn.com/ abstract $=1069953>$.

I. Robeyns, "Are Transcendental Theories of Justice Redundant?", 19 Fournal of Economic Methodology 2, 2012, pp. 159-163.

D. Satz, “Amartya Sen's The Idea of Justice: What Approach, Which Capabilities?”, 43 Rutgers Lam Fournal, 2012, pp. 277-293.

A. Sen, The Idea of fustice, Harvard University Press, 2009.

A. Smith, The Theory of Moral Sentiments, 1759.

A.R. Sorkin, Too Big To Fail: Inside the Battle to Save Wall Street, London, Allen Lane, 2009.

B.T.M. Steins Bisschop, "Bescherming tegen niet geïnviteerde overnames en ongewenst aandeelhoudersactivisme", Oratie Universiteit Maastricht, 2008.

B.T.M. Steins Bisschop \& M.A.W. Römkens, "Integrity and Transparency as Fundamental Notions of Good Governance. But Are They Enforceable?", 5 Tijdschrift voor vennootschapsrecht, rechtspersonenrecht en ondernemingsbestuur, 2014, pp. 150-163.

L.A. Stout, "Bad and Not-So-Bad Arguments for Shareholder Primacy", 75 Southern California Lam Reviem, 2001, pp. 1189-1209.

L. Timmerman, "Some Thoughts on the Impact of Fundamental Rights on Dutch Company Law", in Constitutionalisation of Private Lam, Leiden, Martinus Nijhoff Publishers, 2006.

\section{Legislation}

UK Companies Act 2006.

Jurisprudence

Société Colas and others v. France, no. 37971/97, EHCR 2002-II. 